\title{
The Double in Quest to Save the Protagonist
}

\author{
Kalina Maleska \\ "Blaze Koneski” Faculty of Philology, Ss. Cyril and Methodius University - Skopje \\ Bul. Goce Delcev 9A, 1000 Skopje, Macedonia \\ E-mail:kalinamaleska@gmail.com
}

Doi:10.7575/aiac.alls.v.6n.2p.220

Received: 14/12/2014

URL: http://dx.doi.org/10.7575/aiac.alls.v.6n.2p. 220

Accepted: 19/02/2015

\begin{abstract}
This essay explores the theme of the double in Umberto Eco's The Island of the Day Before, Joseph Conrad's The Secret Sharer and Zivko Chingo's The Big Water. While traditionally the double is connected with the evil alter-ego of the protagonist, what brings these three works together (by an Italian, English and Macedonian author) is the fact that the treatment of the double in them is different from those traditional representations. The essay will argue that, even if it seems that the double is some kind of more evil variant than the protagonist, he is actually summoned in the three selected works by the protagonist in order to save him from loneliness or threat. Still, the levels of real existence of the double, his roles and functions are different in all three works and these aspects will come into light in their comparison. Each work is analyzed in terms of several theoretical assumptions established Chatman, Genette or Steiner, among others, and each is compared with the other two, thus producing the points of resemblance in terms of the two narrative structures that coexist in all three works.
\end{abstract}

Keywords: the double, isolation, alienation, Eco, Conrad, Chingo, ideology

\section{Introduction}

The double, also known by the German word Doppelgänger, in fiction and folklore refers to a kind of an alter-ego of a living person or a fictional character, that physically resembles him/her, and has been frequently connected with the disability of the character to achieve his/her goals, or even as an omen announcing the death of the character. The theme of the double has been used in many literary work, notably in Rober Louis Stevenson's Dr. Jekyll and Mr. Hyde, F. M. Dostoyevsky's The Double or E. A. Poe's story "William Wilson". In all these works, the double represents a kind of an evil spirit, who threatens to destroy the immortal soul of a person.

In the novels and stories of the twentieth century, however, that I would analyze in this essay, the meaning and essence of the double no longer follows closely the folklore understanding of the double as a harbinger of bad luck. The appearance of the Doppelgänger in the three selected literary works is generally caused by isolation, and in affecting the narratives of Umberto Eco's The Island of the Day Before, Joseph Conrad's The Secret Sharer and Zivko Chingo's The Big Water in an almost identical way, the double has brought these, otherwise diverse, works closer together. Namely, unlike the double in many past literary works, who appears as the evil counterparts of the protagonists, the doubles in these three works materialize in order to save the main character - even in the case of Eco's novel, where Ferrante seems like a typical evil Doppelgänger who leads Roberto to despair, and eventually to death, I would argue that Ferrante, in fact, is invented by Roberto in order to save Roberto.

The attitude of the protagonist towards his double, the significance and the function of double in the protagonist's development, however, are very different in these three works, and also provide a great variety of interpretations in comparison to the treatment of the double before the beginning of the twentieth century. Because of the various treatment of the topic of the double, I have decided not to discuss these works in chronological order (The Secret Sharer was published in 1910, The Big Water in 1971 and The Island of the Day Before in 1994), but, instead, to emphasize gradually the difference in treatment. Thus, the first novel discussed is Eco's because the Doppelgänger here is undoubtedly an imaginary character; in the second (Conrad's) story, it is disputable whether the double is real or invented by the protagonist; and, finally, in Chingo's novel, the double is unquestionably a real character, but his characteristics are such that he seems to be a perfect counterpart of the protagonist.

There have been various studies that have discussed the theme of the double from the perspective of psychoanalysis, anthropology, literature. Otto Rank's study, for example, investigates the existence of a double as a means for a person to displace his/her guilt. Among others, he refers to Oscar Wilde or Edgar Allan Poe, claiming that they were pathological personalities, and that the double was a result of their disturbance. Karl Miller in his Doubles: Studies in Literary History explores literary works from the period of Romanticism to the present that have focused on the double. His major idea is that the double is represented as flying or fleeing, which takes the form of a journey in many works. Further on, in her extensive analysis of the treatment of the double in the works of R. L. Stevenson, Wilkie Collins and Daphne du Maurier, Nathalie Abi-Ezzi "locates the origins of the double's representation by those writers as rooted in the Gothic; the main purpose of this is not so much to account for the Gothic conception of the double, but to explore 
the relevance of the genre's externalization of inner fears and the psychological life" (p. 2). Abi-Ezzi emphasizes that there is no strict definition of what the double may refer to because the theme is complex and wide-ranging, but it includes at least both the dopplegänger and the divided self.

In her text entitled "The Soul as Second Self before Plato", Adela Jeng, drawing on several authors who have examined the topic of the double, comes to the conclusion that it was differently understood in ancient Greece based on the Greeks' understanding of the soul in comparison to the time after Christianity has become dominant religion in Europe. In this context, I hope to contribute to the discussion by examining the mentioned works of the Italian writer Eco, the English writer Conrad and the Macedonian writer Chingo in relation to one another, as it may shed light on the assumption that in the twentieth century, the double may seem to be an evil second self whose actions are condemned by society, but simultaneously he (she/it?) may, in fact, be the second self that the protagonist summons to help $\mathrm{him} /$ herself.

In The Island of the Day Before, the protagonist, Roberto, is isolated from all human beings, cast upon a deserted ship somewhere in the Pacific Ocean; surrounded by the ocean, he invents his Double, his nonexistent illegitimate brother Ferrante, who takes over the position of protagonist from Roberto, becoming a part of Roberto's completely invented, contrived romance. In The Secret Sharer it is no longer so clear whether Leggat, the Captain's Double, who appears unexpectedly from the sea, exists in reality or only in the Captain's mind; his existence seems to be more plausible than Ferrante's, and with the story-within-the-story he narrates, Leggat causes changes in the life of the Captain who has received him. In The Big Water, Lem's Double, Kejtan, is seen not only by Lem, but by the other children in the orphanage, so there does not seem to be any doubt that Kejtan, although Lem's Double in terms of his characteristics, is a real boy; it is the harsh conditions in the orphanage near the coast of the Ohrid Lake, and the presence of communist ideology that have invoked Kejtan's emergence and triggered the story to follow Kejtan's actions, rather than Lem's.

\section{Isolation as Cause of Appearance of the Double}

It is no wonder that Eco names the ship on which his hero is shipwrecked Daphne, for this name carries in itself a long legacy, all the way to Ovid's Metamorphosis. It is the name of the girl, who, in the myth and in Ovid's work based on myths, turned into a laurel after she had cast a look on the stream where she arrived running away from Phoebus's pursuit. She was rooted to the ground just as the ship Daphne is now trapped with its anchor dropped to the bottom of the sea, unable to sail away. This fact indicates the entrapment Roberto experiences on the ship, "alone of all our race" (Eco, 1995, p. 1), as he writes in the summer of 1643. Not only Roberto, but the narrator himself, a scholar who had later come across Roberto's letters, and through whose voice we discover Roberto's story, emphasizes the threat that comes from the isolation caused by the ocean: "How many days had he been tossed by the waves, feverish surely, bound to a plank, prone during the hours of light to avoid the blinding sun, his neck stiff, strained unnaturally so as not to imbibe the water, his lips burned by the brine? His letters offer no answer to this question: though they suggest an eternity, the time cannot have been more than two days" (p. 1).

The fact that Roberto cannot swim only increases the menace and the despair, as do his eyes sensitive to sunlight. Roberto was "tossed", "feverish", his neck was "stiff", "unnaturally strained", his lips "burned" - all these notions that evoke the hostility of the ocean gradually increase their power in Roberto's mind, and for a long time he does not decide to reenter the threatening environment.

This anxiety is not shared by the Captain in The Secret Sharer. He, too, is on a ship, and he feels as isolated as Roberto does, although his ship is not abandoned, but, rather, full of people, the crew preparing for the arduous forthcoming journey. Yet, the Captain feels just as lonely because he is new on the ship, has recently been appointed a Captain, but knows the ship and the crew for a very short time, so he considers himself to be stranger to everyone, as much as they are strangers to him. Unlike Roberto, however, he finds consolations on the ship: the rails of the ship seem as "the shoulder of a trusted friend" (Conrad, 2002, p. 254), and he feels safe when he is alone with the ship and sea. On the first night on board the ship, the Captain, who is also the narrator, finds himself completely alone on deck because everybody "was sleeping profoundly". And exactly because of that, he says, "suddenly I rejoiced in the great security of the sea as compared with the unrest of the land, in my choice of that untempted life presenting no disquieting problems, invested with an elementary moral beauty by the absolute straightforwardness of its appeal and by the singleness of its purpose" (p. 256).

It is precisely the Captain's sentiment of security that has prompted him to choose life on the sea, choose rather than find himself as Roberto does, on a ship, on which Roberto does not feel as comfortable as he does on land. The only disturbing noises for the Captain are those from the crew on board the ship - for as long as he is alone, the unrest of the land does not seem to be able to reach him.

Lem from The Big Water, similarly to the Captain, feels comfortable when he is alone, and his only purpose in life is to arrive to the Ohrid Lake he once saw when, after World War II, he was being taken to the orphanage, situated not far from the coast. But, although at reach, the lake is not accessible to him, because the children were never allowed to move beyond the walls surrounding the orphanage, which is identified with prison. While the Captain chose life on the sea, Lem was never given any choice. The lake, nevertheless, remains a symbol of freedom and of strength for him and for all the other children:

Во почетокот ќе спомнам само толку, илјадапати, милионпати, неброено била поголема, посилна страста за убавиот живот и слободата. Проклет да бидам ако тоа не нѐ држеше да 
одиме, да не се плашиме од страшните казни. О вечни, о слатки соништа. Проклет да бидам, тоа беше гласот на големата вода. (Чинго, 1971, p. 7)

In the beginning I will mention but this - a thousand times, a million times, innumerable times greater, stronger was the passion for beautiful life and freedom. Oh, would I be damned if this did not keep us going, if it did not make us unafraid of the terrible punishments. Oh eternal, oh sweet dreams. Cursed be I, it was the voice of the big water.

The big water, the lake, is beyond the walls, epitomizing freedom, a promise of freedom, the thought of which makes the excruciating life more endurable. Its power is so immense that all punishments sustained by the children from the moment they set off towards the orphanage, through the moment they arrived there, and during all the years that followed, seemed bearable, seemed acceptable, when someone only so much as mentioned the lake, let alone see it. And this is exactly what invokes or causes the appearance of the more courageous alter-ego of Lem: Kejtan. With Kejtan's arrival in the orphanage, Lem gains the strength to climb secretly the roof of the orphanage and observe the Ohrid Lake from there.

\section{Losing Control over the Narration}

Cast upon a deserted ship, unable to swim, Roberto's only pastime is to writer letters to his beloved Lilia. In these letters he explains all that happened to him before he had come on board the Daphne. These events are narrated by what Genette calls an extradiagetic narrator - in this case a scholar who has come across the writings of Roberto. This narrator seems to perfectly fit the definition of Genette's extradiegetic narrator as interpreted by Bradford: the extradiegetic narrator remains distant from the story, and the most obvious signal of distancing is the continuous use of the third person account (Bradford, 1997, p. 58). What could be a stronger signal of distancing than a scholar who discusses documents about events in which he had never participated or which he never even witnessed directly? Ay, but not quite so. For rarely does a literary works defy literary theory to such an extent as Eco's.

The scholar in The Island of the Day Before is distanced from the story and gives a third person account, but apart from being a narrator, the structure has simultaneously granted him the opposite role - he is also the reader of the letters left by Roberto, and extracts Roberto's story from the letters, whose narrator is really Roberto, not the scholar. And it is Roberto who gives a first person account of the events that happened to him before he boarded the Amarillys, and then, after the shipwreck of the Amarillys, how he found himself cast upon the Daphne. The narrator is in the same time a reader, and even more than that, he is an interpreter, since he fills in the gaps left in Roberto's letters, which are imbued with metaphors and conceits, expressing Roberto's love to Lilia.

Occasionally, they include chronological events from Roberto's life, and in such cases, the letters are perfect examples of what Roland Barthes has termed functions (1996, p. 139), and Seymore Chatman has termed kernels (1990, p. 112) in the story. From these kernels, the narrator builds up a plot, adding Barthes's indices (p. 143) - or Chatman's satellites (p. 112) - into it, causing variations in terms of atmosphere, mood or pace. Roberto tells us facts and he expresses his love to Lilia. The narrator, on the other hand, interferes where Roberto has left things unsaid or unexplained. The narrator, for example, presupposes what Roberto felt like when he suspected there was an intruder on board; the narrator imagines what Roberto must have had in mind when he set off for his final water journey towards the nearby island - Roberto never came back from that journey to give his own account.

Just like the scholar, Roberto, too, is at the same time both a narrator of his story in the letters, and a narrator, or rather, a creator of another story: a romance as he terms it; moreover he is also part of the narrated discourse because he is a character of his own narration. It is in this romance, that Roberto first invents his double - his evil brother Ferrante.

What has brought Roberto to this situation, to be surrounded by water on an anchored ship and to create a parallel life to the one he lived, is his quest for a solution of the mystery of longitudes. Who knew how to calculate longitudes could master the oceans, and consequently master the world. Before he finds himself cast on a deserted ship surrounded by water, Roberto's life is a chronological chain of events consequentially leading to one another. In the grasp of the ocean, however, the logic of reality starts changing. Isolated, especially after Father Caspar, the only survivor on the Daphne, goes in his aquatic bell to reach the island and never reappears again, Roberto's sense of reality starts to change.

Once completely isolated and lonely, he faces his double, that is, imagines a story of his illegitimate brother Ferrante who tries to take over Roberto's beloved Lilia. His Doppelgänger Ferrante causes Roberto to invent the double narrative of The Island of the Day Before, which Roberto himself will later enter in order to save himself and his beloved. This, the real and the imaginary world get interwoven with each other. This double narrative is a deviation in terms of the primary narrative - imaginary events are concocted where previously real ones (about Roberto's life) were told; the evil villain takes over where once a hero thirsty for knowledge lived; a romance unfolds after the examples of Alexandre Dumas' novels where formerly historical events occurred and historical persons (such as Richeliue) ruled. Not only the content, but also the structure varies: it is not only that there is a villain instead of a hero, or that the story is filled with fantastic occurrences replacing the real ones, but also the logic of the structure alters.

After the disappearance of Father Caspar beneath the Ocean, Roberto is left utterly alone and begins analyzing the events of his past. One day he remembers that when he was young, his father used to tell him: you are my firstborn! Until that point, he thought that he was the only son, but the term "firstborn" now seems to indicate that there was another son, too, younger than himself. Another day he recalls that Lilia said to him: you were not so shy yesterday this seemed a little strange to him at the time, because he did not see her the previous day, but only now does he start to 
wonder who she was actually talking about? Was it someone that resembled him so much that Lilia thought it was him? Roberto is said to have always been prone to daydreaming, but he never, in fact, invented such a comprehensive story, as now, on board a deserted ship. It is his loneliness that brings his double, Ferrante, to life.

Roberto begins his romance as an omniscient narrator, who is in control of the plot he is narrating. He considers important questions in the process of storytelling and makes decisions as to when and where to begin, or what his characters should be like and by what method he was going to describe them. Soon, however, gradually and surreptitiously, his anger at the jealous, evil brother, who wants to destroy him and to have a short insignificant affair with the love of his life - Lilia, deprives Roberto of his control as a narrator. Instead of the omniscient point of view, with which he began his story, Roberto now plunges into the story, becomes a part of it. As a character inside the story, he is mad when Lilia kisses the fictive Ferrante believing him by mistake to be Roberto.

At that outraged excess, forgetting that she was giving to Ferrante, believing him Roberto, the proof that Roberto had so desired, he hated Lilia, and running about the ship, he howled: "Oh wretch! I would offend all your sex if I called you woman! What you have done is more proper to a fury than to a female, and even the title of beast would be too great an honor for such an animal of Hell!" (Eco, 1995, p. 384)

He gathers his strength and resumes his objectivity after leaving the story for a couple of days to exercise swimming with a rope around his body, tied to the ship. This interchange of different focalizations is further complicated when Roberto becomes in the same time a character and a narrator, when he takes out of his memory all past events in which he participated and gives them meaning they did not have before, meaning brought about by Ferrante's concealed presence in the background. Thus, contrary to Roberto, who enters the imaginary story from the real world, his double Ferrante, the invented villain brother, exits the realm of the imaginary discourse and walks right into real life. Now, the omniscient narrator Roberto materializes all fabricated events and characters and gets absorbed in the narrative structure which has become incarnated into reality. "Out of love, Roberto decided to perform that feat, entering the story himself" (p. 496). Thus, to save the dying Lilia, whom he imagined cast upon the island of the day before, which he could see from the ship, the island on the other side of the $180^{\text {th }}$ meridian, where it was still the previous day, so he could still save her, Roberto burns the Daphne and plunges into the unconquerable water. What later happened to Roberto remains unknown.

\section{Romance as the Embedded Story in Eco's Novel}

The other alternation of the logic of the structure, caused by the appearance of the double, refers to the properties of the romance as a genre. Creating the story of Ferrante, Roberto enters the world of romance in which, instead of the usual hero, the protagonist is a villain. Roberto, nevertheless, manages to retain the characteristics of the genre by including himself in the story as the hero in quest of the mystery of longitudes and striving to deserve the love of a beautiful lady.

Although the protagonists of Roberto's romance do not possess magic powers, their abilities are, nevertheless, marvelous. Roberto bravely fights at Casale, he has an extraordinary gift for easily learning languages, he is honorable towards his beloved and principled in regard to the secrecy of his quest just as any hero of a romance. Neither does Ferrante lag behind with the remarkable expression of his evil: he betrays the French, on whose side he was pretending to fight at Casale; he manages to eliminate all his enemies obliquely, never directly; he has an almost supernatural talent to deceive; his villainy towards soldiers and helpless ladies is excessive; and as if by magic he appears at exactly the right place and the right time to use the information he has to his advantage. Everything that is happening in the imaginary tale accords with Northrop Frye's analysis of romance in his Anatomy of Criticism: "The hero of romance moves in a world in which the ordinary laws of nature are slightly suspended: prodigies of courage and endurance, unnatural to us, are natural to him, and enchanted weapons, talking animals, terrifying ogres and witches, and talismans of miraculous power violate no rule of probability" (1957, p. 33).

Nothing before the appearance of Ferrante resembles any trait of romance. There was no winning of the lady's favor for Roberto before he sailed off on board the Amaryllis - they seem to have only exchanged a few sentences. Roberto truly had a talent for learning languages, but that was his greatest strength and by no other quality was he any different from others. On the contrary - his eyes were extremely feeble, he could not stay out in the sunlight; he was unable to swim this is what bonded his destiny to the Daphne. He did no chivalrous acts, nor showed any extraordinary courage or endurance. "Nothing more than solitude encourages suspicion, nothing more than daydreaming transforms suspicion into certainty," (Eco, 1995, p. 366), and narrator says, and indeed, once he remains alone in the middle of nowhere, jealous that someone else may have Lilia, Roberto decides to construct his own story, the story that takes the position of a double narrative in The Island of the Day Before.

He thought, namely, that he may construct a story, of which he was surely not the protagonist, inasmuch as it would not take place in this world but in a Land of Romances, and these story's events would unfold parallel to those of the world in which he was, the two sets of adventures never meeting and overlapping.

What would Roberto gain by this? Much. By inventing the story of another world, which existed only in his mind, he would become that world's master, able to ensure that the things that happened there would not exceed his capacity of endurance. On the other hand, as reader of the story whose author he was, he could share in the heartbreak of its characters." (p. 367) 
All reasonable arguments, but not when taken together, the narrator comments. These reasonable arguments make the tale advance step by step; as it moves spatially away from the intended terrain, it affects its jealous inventor psychologically, who, together with the story, moves further towards the unknown.

In fact, losing his ability to distinguish between reality and fiction is what paradoxically reveals the function and meaning of Roberto's double. In writing a romance, Roberto realizes that it would not be complete without a villain this is how Ferrante comes into life. He appears because of the unbearable and extensive loneliness of Roberto on the ship; he appears because Roberto cannot find a way out; and, finally, he appears so that Roberto can find strength to swim to the island and save Lilia from the evil Ferrante. So, it is precisely because Ferrante is evil, dangerous and threatening that he can actually save Roberto from the meaninglessness of the days spent on the ship. Roberto is desperate being alone and isolated on a ship for months, and it is this despair that Ferrante saves him from. Roberto has created his double in order to find a justifiable reason for attempting to swim to the island - otherwise, because of the fear of water, he would never dare try. The most probable outcome is that Roberto drowned in the course of doing this, so his Doppelgänger lead him to death. Yet he equally stands for Roberto's refusal to continue living alone on a deserted ship for the rest of his life, and from this point of view, Ferrante has saved Roberto from that misery.

\section{First and Second Narrative Line not Easily Distinguished in Conrad's Story}

In the case of Conrad's and Chingo's stories there looms the question, in different degrees, whether the Double was real or imaginary and whether the double narrative is told by a voice different from the one narrating the frame story. To understand the appearance of the double in Conrad's story, it is very important to understand the state of mind of the Captain in the very beginning. Being newly appointed and not knowing anyone on board, the Captain has an internal struggle: he does not know how to approach the men as this is the first time he has to sail the very next morning after meeting them for the first time. He does not know the ship either and spends the whole night walking on deck in the hope of learning something about it before he sets sail.

Conrad is certainly no stranger to the double narrative technique; in fact, The Secret Sharer shares the structure of his famous Heart of Darkness in regard to the frame and the embedded story. The double vision raised in The Secret Sharer has its impact on both the interpretation of the content with its psychological profundity and on the structure. This is what Erdinast-Vulcan in his "Some Millennial Footnotes on The Heart of Darkness" writes on Heart of Darkness: "I have suggested that Marlow's narrative should be read as performative speech act because it does not represent a given truth but generates its truth in the act of telling" (2005, p. 57), and the same is certainly valid for The Secret Sharer. Indeed, just like The Island of the Day Before, Conrad's story does not aspire to telling the truth, or a truth for that matter, it does not judge whether the events are unlikely to have happened or whether the narrator of the embedded story is unreliable. The act of telling, the act of providing a second narrative, whose point of view differs from the first one, is the act that causes instability to rise and refuses to settle a given truth.

And just like in The Island of the Day Before, it is the loneliness that brings forth the emergence of the double. Alone on deck, after sending the others to sleep, an uncommon practice on ships, the Captain notices the stranger hung by the ship's ladder. It is in the Captain's room that Leggat is narrating the chain of events that led him to where he is now. The events before the appearance of "something elongated and pale floating very close to the ladder" (Conrad, 2002, p. 257), which is Leggat himself, cannot rightfully be called events as it is the description of the environment in which the ship is anchored, the atmosphere of isolation, tranquility, loneliness, distance from the others that occupy the narrative before the appearance of Leggat.

But what I felt most was my being a stranger to the ship; and if all the truth must be told, I was somewhat a stranger to myself. The youngest man on board (barring the second mate), and untried as yet by a position of the fullest responsibility, I was willing to take the adequacy of others for granted. They had simply to be equal to their tasks; but I wondered how far I should turn out faithful to that ideal conception of one's own personality every man sets up for himself secretly. (p. 255)

This atmosphere of seclusion, remoteness, serenity, even admonition, permeates the beginning of the narrative, while the feeling of wonder and uncertainty announces the shattering of the "ideal conception". The fact that these subjective feelings predominate the story is due in part to the type of narrator, different in comparison to the narrator of The Island of the Day Before: in Conrad's story, the narrator - the Captain in this case - is intradiegetic (in Genette's terms), and he is neither objective nor distanced from the story, but is a participant in the events that are filtered through his perception.

The emphasis on emotions and atmosphere gives way to Leggat's story, while they are both hidden from the eyes of the crew in the Captain's chamber. The double narrative assumes its own shape, opposed to the shape of the Captain's recounting: it accelerates the tempo of the story, it is filled with so rapid events that only in a few paragraphs the reader comes to witness developments that lead to a murder committed by Leggat, the narrator of the embedded story. This, in fact, represents the need of the Captain to start acting instead of focusing on the atmosphere on board the ship. When he concludes telling about the occurrences that led to his escape, the Captain takes over as a narrator. But by this time, his double has already affected him: the narrative tone and style have already changed. The Captain is on the alert, no longer embodying the concept he had of himself in the beginning, but becomes a rebel against the current order, helping an outlaw, his thoughts busy with how he can rescue Leggat, the uninvited, yet congenial double. Thus, the Captain, frightened in the beginning of the journey, finds strength within himself to command the ship bravely. In that sense, 
Leggat is certainly the alter-ego of the Captain, his internal courage, summoned by the Captain himself to relieve him of fear and uncertainty, to prepare him for action, rather than contemplation.

The circumstances by now have changed dramatically in comparison to the beginning of the story. In the beginning, the sea near the Paknam pagoda was so calm that it resembled more a flat ground than water surface, so incredibly peaceful that there could not be any doubt in the impossibility for it to stay like that for long. Despite the short duration of those moments, however, the appearance of tranquility managed to transpose itself on the Captain, and he was inclined to believe that all that surrounds him - the sea and the ship and the crew on board the ship are in harmonious coexistence, in which all know their role. It does not take long, however, for this balance to be disturbed. On its surface, another ship, the Sephora, floats unusually positioned between the islands, as all other ships. In these unusual circumstances, the Captain adds yet another uncommon episode - he orders everyone to get a rest in their rooms without setting an anchorwatch, but decides to perform the watch himself.

\section{Farewell to the Double}

The sea is merciless in daring the Captain - he barely has time to cast a single look on the ship during his own anchorwatch, when he is faced with the stranger escaped from the Sephora. He barely accommodates his unexpected guest and hears the story of how he murdered a man, when he confronts the Captain of the Sephora on his decks. He does not have much time to think in these two situations - he has by now already become entangled in the double narrative, where crucial points in time will cause events to turn into one direction or another - and he has to react rapidly. The concept he had of himself in the beginning is now disrupted; will that bring about his growth or his demise? Thanks to his encounter with his double, the threats from the captain of the Sephora seem to strengthen him, and, although in the beginning he presents himself as hesitant, which was reflected in the narrative structure, the dangers awaken his readiness for action. He sends away the Captain of the Sephora, who is searching for the escaped criminal, and convinces him that no outlaw has come close to the ship.

The ultimate test is still to come. It is a test in which he has to save not only Leggat and the ship, but also himself as a person - Leggat being a part of himself actually means that by saving Leggat he is at the same time saving himself and his reputation in the eyes of the crew, whose members saw him as irresolute and watched him critically. So, he must make a resolute decision - to draw the ship near Koh-ring, so that Leggat would be able to swim to the coast, whereas in the same time he could justify this hazardous enterprise to the crew by presenting it as a way for the ship, which sailed too slowly, to catch the land wind and gain velocity. Unlike in the beginning, when no risky endeavors seemed to be in sight, now, after the double has left his trace forever on the further developments, the Captain faces a situation in which they could all die or they could set off on the intended journey.

When I opened my eyes the second view started my heart with a thump. The black southern hill of Koh-ring seemed to hang right over the ship like a towering fragment of the everlasting night. On that enormous mass of blackness there was not a gleam to be seen, not a sound to be heard. It was gliding irresistibly towards us and yet seemed already within reach of the hand. I saw the vague figures of the watch grouped in the waist, gazing in awed silence. (Conrad, 2002, p. 280)

And although all the crew members with frightened and unsteady voices ask whether it is a good idea to continue this dangerous venture, and a few voices even cry out that the ship has hit the rocks, the Captain continues to carry out his idea, turning the ship around just in time to save it and to sail away faster with the land wind behind their backs. The Captain saves the ship, saves his reputation in the eyes of the men on board who admire him after he proves to be capable of carrying out his task, and saves Leggat, whom he sees, thanks to the white hat Leggat was wearing, swimming towards the coast.

Walking to the taffrail, I was in time to make out, on the very edge of a darkness thrown by a towering black mass like the very gateway of Erebus - yes, I was in time to catch an evanescent glimpse of my white hat left behind to mark the spot where the secret sharer of my cabin and of my thoughts, as though he were my second self, had lowered himself into the water to take his punishment: a free man, a proud swimmer striking out for a new destiny. (Conrad, 2002, p. 282)

In this way, by saving the stranger that resembles him, he has actually initiated himself as a firm and resolute Captain. He has released his second self to be free and proud, and as the secret sharer of his thoughts strikes out for a new destiny, so does the Captain.

In the beginning, the Captain is divided into two personalities: the hesitant, frightened newly appointed Captain, and the resolute person he wishes to become. And he decides to summon that part of himself, the hidden courage beneath the fear - thus materializing Leggat. Even if it seems very probable that Leggat may be a real escaped criminal, still his much more important role is as the invoked double of the Captain. At the end, the double, making the Captain a kind of split personality, has to disappear, to become absent from the story, so that the Captain's inner self can be unified in the person he has wished to be.

\section{Communist Ideology in Chingo's Novel}

In The Big Water there is a persistent existence of gaps: the questions of how the big water from the title, the Ohrid Lake, could alleviate the pain of the orphans, or if the Senterlev Hill really existed, or who the father of the administrator, comrade Ariton Jakovlevski, was, or whether Kejtan's laughter was sincere or designed to irritate Ariton Jakovleski - are never answered; the answers are absent from the novel. 
What differentiates the double narrative in Chingo's novels from the other two previously discussed is the fact that the double is not a real double in the sense of a person only imagined or seen by the protagonist. Kejtan is undoubtedly a real child, but his characteristics are such that he seems to function as a perfect double of Lem. The beginning introduces certain vocabulary and language, typical of the authoritarian ideology that overwhelms the events in the novel (taking place after World War II), whereas the appearance of Kejtan causes a narrative, which represents a respite from the imposed ideology, a respite composed of vocabulary and grammar completely different from the one that prevailed in the beginning. This time, too, just as in The Island of the Day Before and The Secret Sharer, it is water that brings the Double of the protagonist.

The two narrative lines, although more intertwined than in the other two novels, are, nevertheless, just as easily discernable because of the different codes of representation that the author uses when he presents them. The primary narrative represents events from the dreadful reality of the orphans taken to an orphanage ironically called "Light" after they had lost their parents in the recent World War II or in the diseases caused by poverty due to the war. The most noticeable discourses in this narrative line are the descriptive and the chronological discourse. The cold weather, the snow turning all flowers into ice; the torn pants the orphans were wearing, the pitiable row they made when walking towards the orphanage - these images prevail in the story when the Ohrid Lake and Kejtan are absent from it. The events that compose the story: the arrival at the orphanage, getting to know the building blocks of this institution, the walks in the yard inside the tall hostile wall, the audition and selection of talents, the appearance of lice - are all narrated with a tone of sadness and fear, at times even disgust. The one most remarkable, most constant, ever-present character in it is the administrator with authoritarian methods, Ariton Jakovleski. His direct speech, and his speech indirectly conveyed through the narrator's (Lem's) voice are what signify the most typical characteristics of the language in the first narrative line. Ariton's language is a language that is not meant to attempt to express the truth, or to be straightforward, or to provide the so much needed help in the orphanage, but, rather, as Steiner wrote of the German language at the hands of the Nazis, it was meant to be used as a "political weapon" whose aim was to "degrade the dignity of human speech" (Steiner, 1990, p. 347).

It is a procedure well known to Ariton Jakovleski, with which he plunges into the realm of accepted notions carrying a positive connotation, and transfers them into the sphere of manipulation to label with them what would otherwise be a forbidding and nauseous experience. In order to be able to retain the prearranged order in the orphanage, Ariton calls Lem a commendable child, whose role is, just as the role of any commendable child, to keep an eye on the bad children and report on their misbehavior, thus hiding the notion of treacherous behind the term commendable. Similarly, Ariton borrows from the basest vocabulary to offend Kejtan for his lack of a characteristic, as he terms it. The humiliation and torture is performed with Ariton's use of such words as „магаре“, „мрзливец“, „неспособен“, „куче“, „копиле“ (Чинго, 1971, p. 83) (“donkey", "lazy boy", "incapable of anything", "son of a bitch", "bastard"). The characteristic he refers to is, in fact, for Kejtan to become more similar to him: to respect the existing order, not to laugh, to sneer at the others, to honor humiliation. The traditional grace of the notion of a person having a character, entailing positive characteristics, is replaced here with its opposite, with baseness otherwise not related to the term character. Kejtan, however, is well aware of the linguistic manipulation carried out by the administrator, and therefore refuses to accept it, even at the price of harsh punishment.

\section{The Ohrid Lake as a Symbol of Mother's Love}

The double narrative line concerns much more the emotive discourse and the discourse of fantasy or incredible phenomena. It is not, as was the case with The Island of the Day Before and The Secret Sharer, concerned with descriptions, nor does it hold any kernels, but is composed solely of satellites. Crucial events that would lead to consequences for the action are not situated in this double narrative, but it, nonetheless, contains feelings and deliberations that are crucial both to the characters of the protagonists and to the entire atmosphere of the novel, the atmosphere that permeates the life in the orphanage. It is a narrative caused by the presence of water, and it is Kejtan who makes the lake's presence known to the others. From that point onwards, the lake enters the hearts and souls of children. „Погледај“ (“Look at it”), Kejtan says, „ете таму, онаму каде што свети како оган, ене“ (Чинго, 1971, p. 15) ("there, where it glows like fire, there"). The incredible, fantastic moment is precisely this ability of water to assume the form of air and fill the lungs and bodies of people with its presence. It is the overwhelming experience that stays in their memory forever and opens the possibility for multifold meanings:

По малку патување, пред нас се откри најубавата, најтаинствената слика на мојот живот. Големата вода! Огромна, чудесна. О, боже! Мил боже, нѐ пречека со мајчински очи, со светол и благ поглед. Во мигот занемев, се колнам.

\section{Децата како под команда застанаа.}

- Доаѓa! - кликнаа децата како птици.

- Таа ќе дојде, - еден непознат глас ни се јави, една непозната жена сета во црно полека доажаше кон нас. Тоа беше мајка Верна Јаковлеска, добрата мајка Верна Јаковлеска.

Jac cè уште ја гледам таа вода. Кејтеновиот сон, нашиот сон. Проклет да бидам, сиот наш сон. Крај водата можевме да пропатуваме уште толку дни и уште толку ноќи, можевме да одиме без прекин еден век. Цел еден век. Уморот, тешкиот пат, гладот и жедта што нѐ следеа со часови додека нѐ носеа во домот завчас исчезна, божем сета наша мака, несреќи ги стопи добрата душа на Големата вода. (Чинго, 1971, p. 16) 
After a short while, the most beautiful, the most mysterious image of my life appeared before my eyes. The big water! Enormous, miraculous. Oh, God! Dear God, it greeted us with mother's eyes, with bright and delicate look. I was utterly impressed, speechless, I swear.

The children stopped as if under command.

- It's coming! - they shouted like birds.

- It will come, - an unfamiliar voice said, an unfamiliar woman dressed in black was coming towards us. It was mother Verna Jakovleska, the good mother Verna Jakovleska.

I still see that water. Kejten's dream, our dream. Oh, I will be damned, our entire dream. Along the water we could travel as many days and as many nights, we could walk incessantly for a century. An entire century. The exhaustion, the difficult road, the hunger and the thirst that followed us for hours while they were taking us to the orphanage disappeared in a second, as if the soul of the Big Water melted down all our miseries and misfortunes.

The water that entered the souls of the children never abandoned them. Whenever Lem talks about it, he contrasts the feelings of misery and agony that not only him, but all the children experienced in the orphanage to the feelings of comfort, consolation and hope that water provided. The sight of the lake, as seen from the roof of the orphanage, meant freedom to Lem and Kejtan, meant that they could, even if only with their eyes, surpass the walls of the enclosed yard, to encounter a world in which the rules of Ariton Jakovleski did not have any power. Water, by providing comfort to the orphans, is almost always identified with the notion of the mother, the mothers that the children lost in the war - and, through it, with pure and unconditional love. That is exactly why the figure of the mother, carved by Kejtan, containing in itself the power of mother's love and the power of the water associated with the mother, was the reason for Ariton's defeat and death at the end of the novel. In the last chapter, entitled "The Coming of the Big Water", in moments that linger between reality and fantasy, Ariton's repressive principles and rules, supported by the state system, eventually disintegrate when faced with the wooden figure, epitome of the lake and the mother's love.

There is a significant difference in terms of the form of the narrative lines in this novel as compared to the other two novels, and this regards the place the double narrative assumes within this The Big Water. Unlike the double narratives in The Island of the Day Before and The Secret Sharer, the double narrative in The Big Water is not an embedded narrative, but, rather, it occurs, retreats and again reoccurs throughout the novel.

Each change of narrative level in a recursive structure also involves a change of ontological level, a change of world. These embedded or nested worlds may be more or less continuous with the world of the primary diegesis, as in such Chinese-box novels as Wuthering Heights, Lord Jim, or Absalom, Absalom!; or they may be subtly different, as in the play-within-the-play of Hamlet, or even radically different, as in Hofstadter's dialogue. In other words, although there is always an ontological discontinuity between the primary diegesis and hypodiegetic worlds, this discontinuity need not always be foregrounded. (McHale, 1987, p. 113)

Having a recursive structure and being a realist novel, The Big Water displays the change of narrative level, which, as McHale explains, is continuous with the world of the primary narrative line. The double narrative, comprising fantastical and emotional elements, functions as a link in the chain of narrative transmission because it does not disintegrate the primary chain, but rather exists within it, offering comfort and repose from the cruelty of the surrounding reality precisely because it is Kejtan, the double as well as the soul mate of Lem, who plays a major part in it.

\section{Conclusion}

All three Doubles - Ferrante, Leggat and Kejtan - are something negative in terms of the socially accepted and acceptable codes: Ferrante is a villain, Leggat - a murderer, Kejtan - the disobedient boy, whose name and laughter also associate him with Satan. As the events progress, the stories move away from the familiar environment and make way for the appearance of the socially unacceptable Double, who takes over the protagonist's actions and thoughts that the protagonist could not express before. However, while Lem and the Captain accept the Double that society rejects, Roberto deems Ferrante a negative person, a villain, who in this rotten world has a way to make the best for himself. Ironically, however, Ferrante is invoked by Roberto to take over the guilt for his bad choices, thus making Roberto purer in his own eyes, and finally saves him from his deteriorating mental state caused by long-time isolation from people.

What brings these works together is the fact that they all deal with the theme of the Doppelgänger. In The Island of the Day Before, it is clearer than in the other two narratives that the Double is invented - he is a character of a story and he is able to do what Roberto, because of his seclusion, cannot do. In The Secret Sharer, there is more doubt as to whether the Double is real or just invented by the lonely newly-appointed Captain, alienated from the unknown sailors. Ironically enough, in The Big Water, where it is almost certain that the Double really exists in the objective reality surrounding Lem, the narration of both Lem and Kejtan seems to come from just one voice, one person, whereas in The Island of the Day Before, where Ferrante is almost unquestionably invented, his voice is completely different from that of his creator, Roberto. So, in Chingo's novel, two different persons speak as if they are one single person, while in Eco's novel, one person speaks in two distinct voices. And in all three stories, the double saves the protagonist either from mental deterioration because of loneliness; from fear of the unknown; or from fear of the authoritarian ideology. 


\section{References}

Abi-Ezzi, N. (2000). An analysis of the treatment of the double in the work of Robert Louis Stevenson, Wilkie Collins and Daphne du Maurier. PhD thesis submitted to King's College, University of London, 2000.

Bradford, R. (1997) Stylistics. London: Routledge.

Chatman, S. (1990). Story and narrative. In D. Walder (Ed.), Literature in the modern world: Critical essays and documents (pp. 105-15). Oxford: Oxford University Press.

Conrad, J. (2002). The secret sharer. In J. Beaty, A. Booth, J. P. Hunter, K. J. Mays (Eds.), The Norton introduction to literature ( $8^{\text {th }}$ ed.) (pp. 253-8). New York: Norton.

Eco, U. (1995). The island of the day before. (W. Weaver, Trans). New York: Harcourt.

Erdinast-Vulcan, D. (2005). Some millennial footnotes on the heart of darkness". In C. M. Kaplan, P. L. Mallios and A. White (Eds.), Conrad in the twenty-first century: Contemporary approaches and perspectives (pp. 55-67). New York: Routledge.

Frye, N. (1957). Anatomy of criticism: Four essays. Princeton: Princeton University Press.

McHale, B. (1987). Postmodernist fiction. New York: Methuen.

Miller, K. (2009). Doubles: Studies in literary history. London: Faber.

Ovid, P. N. (2008). The metamorphosis. Project Gutenberg: Retrieved from http://www.gutenberg.org/files/26073/26073-h/26073-h.htm

Rank, O. (1989). The Double: A psychoanalytical study. Harry Tucker (Trans.). London: H. Karnac).

Steiner, G. (1990). The hollow miracle. In D. Walder (Ed.), Literature in the modern world: Critical essays and documents (pp. 346-51). Oxford: Oxford University Press.

Барт, P. [Barthes, R.]. (1996). Увод во структуралната анализа на раскажувањето [Introduction to the Structural Analysis of Narratives]. In Атанас Вангелов (Ed. and trans.), Теорија на прозата (pp. 129-78). Скопје: Детска радост.

Чинго, Ж. [Chingo, Z.]. (1971). Golemata voda [The Big Water]. Скопје: Македонска книга. 